\title{
Water gain and water loss of some freshwater aquaculture ponds at Kausalyaganga, Orissa, India
}

\author{
S. Adhikari ${ }^{1}$ (D) K. C. Pani ${ }^{1} \cdot$ P. Jayasankar ${ }^{1}$
}

Received: 6 March 2017 / Accepted: 3 June 2019 / Published online: 8 June 2019

(c) The Author(s) 2019

\begin{abstract}
Hydrological data were collected from the six ponds of 0.05 ha size in the farm of the Central Institute of Freshwater Aquaculture, Bhubaneswar, India. Data on rainfall, run-off, evaporation, and seepage were collected from these ponds for the years 2013 and 2014. The rainfall was $175 \pm 3.0$ and $202 \pm 5.0 \mathrm{~cm}$ in 2013 and 2014, respectively. The run-off was $36 \pm 1.2$ and $29 \pm 1.0 \mathrm{~cm}$, in these ponds, in 2013 and 2014, respectively. Average evaporation was $0.30 \mathrm{~cm} / \mathrm{d}$ in 2013 and $0.37 \mathrm{~cm} / \mathrm{d}$ in 2014. The average seepage was $0.22 \mathrm{~cm} / \mathrm{d}$ in both the years. The loss from the evaporation and seepage could be compensated through the regulated inflow of groundwater from wells/canals. The total amount of well/canal water in an average year to compensate the water loss through evaporation and seepage was calculated and for the 1.0 ha pond, $9800 \pm 200 \mathrm{~m}^{3}$ of water in 2013 and 13,700 $\pm 300 \mathrm{~m}^{3}$ of water in 2014. Accordingly, the harvested water could be 12,000 $\pm 200 \mathrm{~m}^{3}$ in 2013 and $15,000 \pm 300 \mathrm{~m}^{3}$ in 2014 , respectively. The consumptive water use was $3.15 \pm 0.3 \mathrm{~m}^{3} / \mathrm{kg}$ fish and $3.35 \pm 0.2 \mathrm{~m}^{3} / \mathrm{kg}$ fish in 2013 and 2014, respectively. The total water use in these embankment ponds was $5.15 \pm 0.5 \mathrm{~m}^{3} / \mathrm{kg}$ fish and $5.66 \pm 0.6 \mathrm{~m}^{3} /$ $\mathrm{kg}$ fish in 2013 and 2014, respectively.
\end{abstract}

Keywords Rainfall $\cdot$ Run-off · Evaporation $\cdot$ Seepage $\cdot$ Water budget $\cdot$ Aquaculture

\section{Introduction}

Availability of freshwater is reducing day by day, and it is important to know about the minimum requirement of water for the production of $1 \mathrm{~kg}$ fish. Thus, water budgeting is important for one $\mathrm{kg}$ of fish production. Water budget for some watershed has been reported by Shelton and Boyd (1993). Water budget was done for some experimental ponds of Alabama (Boyd 1982). Green and Boyd (1995) developed water budget for some ponds in the dry tropics. In all the cases, they had considered evaporation loss, seepage loss, annual rainfall, and water inflow-outflow. Thus, water budgets are useful for the estimation of requirements of ponds that rely on rainfall and run-off as primary water sources and for flow-through pond facilities. Such budgets will also be able to predict whether existing potential source will be able to meet the projected water demand of aquaculture facilities, and also in comparing the value of available water

S. Adhikari

subhendu66@rediffmail.com

1 ICAR-Central Institute of Freshwater Aquaculture, P.O.-Kausalyaganga, Bhubaneswar 751002, India for different agricultural proposes (Nath and Bolte 1998). Verma et al. (2010) reported that water expense to produce a single spawn of common carp, Cyprinus carpio, in the hatchery system was 0.56 litre (L), while the water expended to produce one fry was $4.86 \mathrm{~L}$. Water requirement for one complete cycle of fibre-reinforced plastic (FRP) material for carp hatchery operation for rohu, Labeo rohita, was $105-136.3 \mathrm{~m}^{3}$, when spawn production in number ranged between 0.7 and 1.4 million per operation in field condition. It was estimated that the water requirement per 0.1 million rohu spawn production ranged between 8.86 and $15.01 \mathrm{~m}^{3}$ (Mohapatra et al. 2016). Sharma et al. (2013) reported that the water requirement for semi-intensive carp culture with supplemental feeding was $10.3 \mathrm{~m}^{3} / \mathrm{kg}$, out of which $7.6 \mathrm{~m}^{3} /$ $\mathrm{kg}$ was system-associated requirement.

The water use rates in eight brackish water shrimp ponds in Chachoengsao, Thailand, varied from 0.63 to $0.95 \mathrm{~cm} / \mathrm{d}$ (Braaten and Flaherty 2000). The water use rates in catfish ponds in Alabama and fish ponds in Honduras were 1.16 and $0.87 \mathrm{~cm} / \mathrm{d}$, respectively (Boyd 1985; Green and Boyd 1995). The water use rate for coastal shrimp ponds was $0.71 \mathrm{~cm} / \mathrm{d}$ in Thailand (Briggs and Funge-Smith 1994). Thus, it is evident that so far as aquaculture pond is considered in India, 
the report on hydrological parameters and water budget for aquaculture practices is scanty. Thus, the present investigation was made to evaluate the important hydrological parameters in some aquaculture ponds in the Central Institute of Freshwater Aquaculture, Kausalyaganga, Orissa, India, to develop water budget.

\section{Materials and methods}

Field studies were conducted in six ponds in the Central Institute of Freshwater Aquaculture, Orissa, India (latitude: 20¹1'06"N; longitude: 85 50'52"E and msl: 33 m; Fig. A). All ponds were approximately 0.05 hectare in size (Fig. B). The Central Institute of Freshwater Aquaculture consists of around 350 ponds ranging from 0.01 to 4.0 ha in area with depth running from 1.0 to $4.5 \mathrm{~m}$.

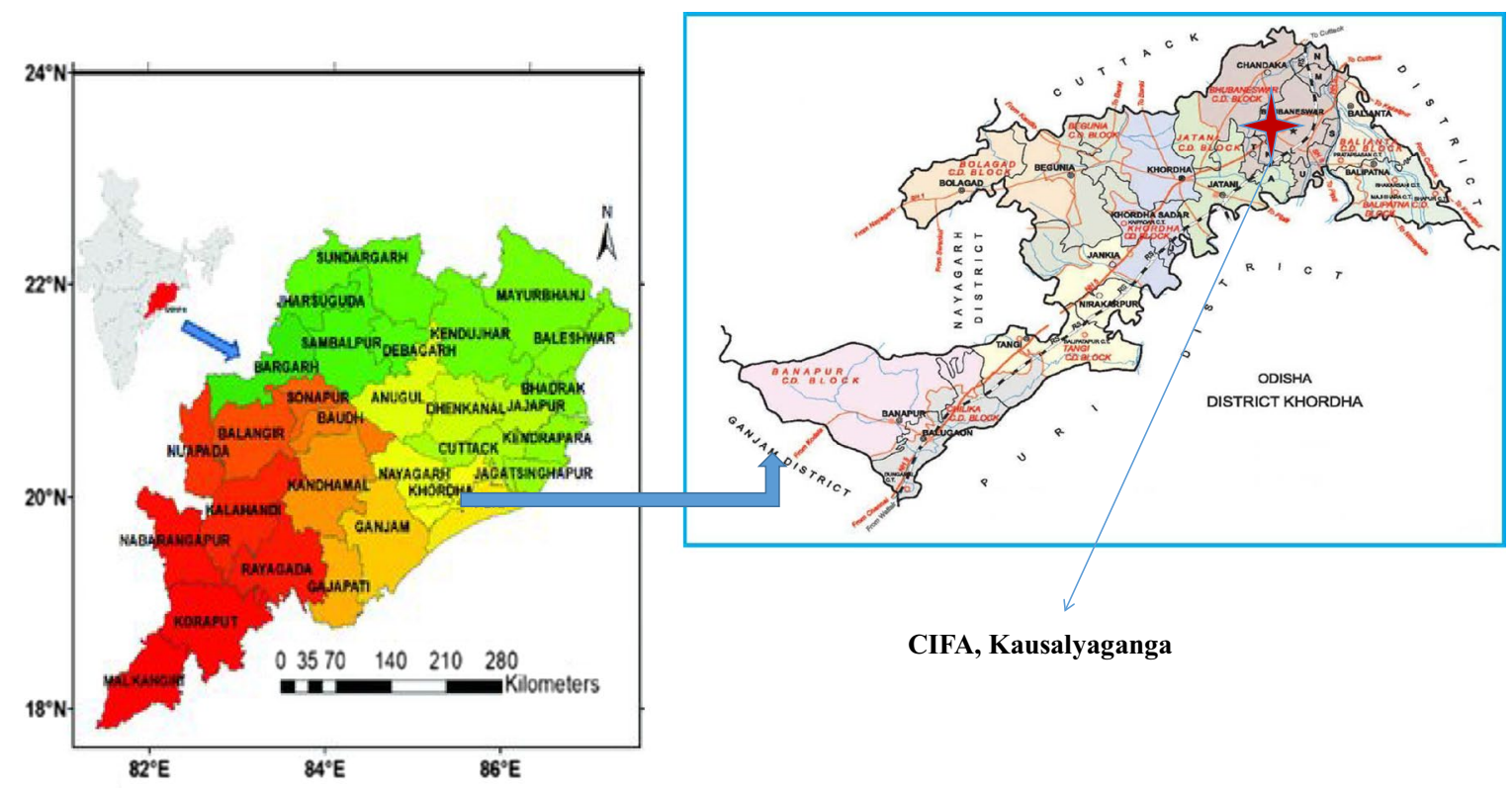

A Location of Odisha state experimental area CIFA, Kausalyaganga

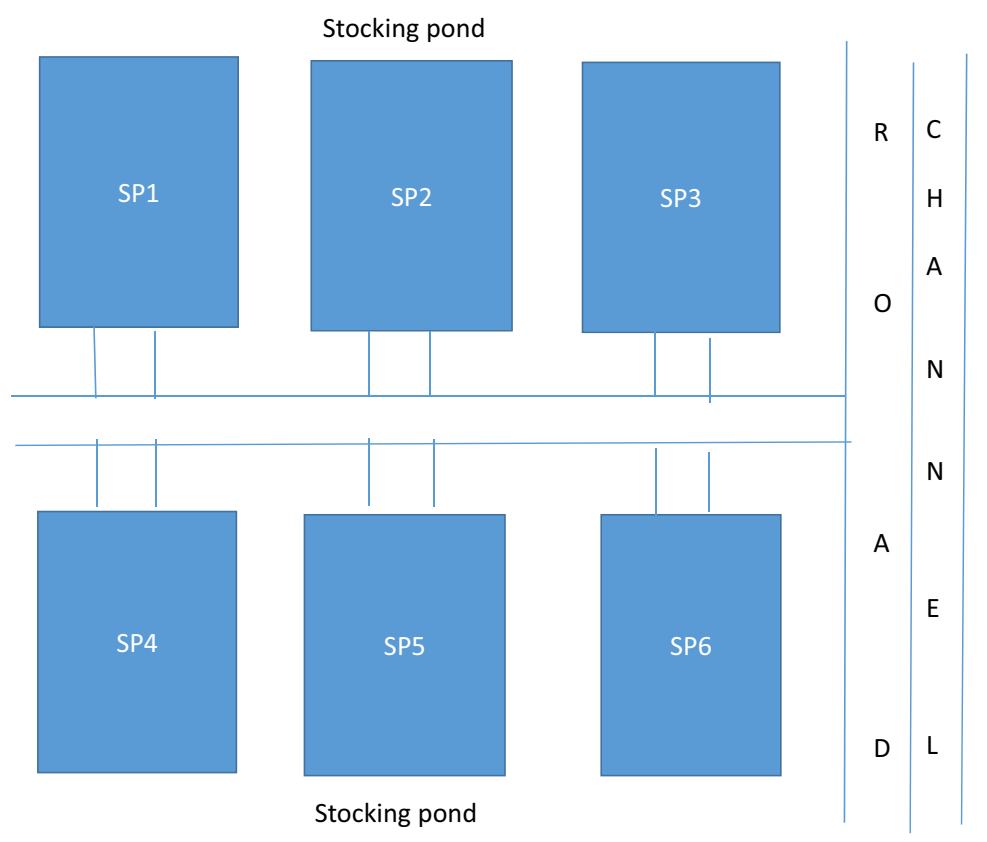

B Layout of experimental plot 
The rainfall was measured at the pond site using standard rain gauge, and the data were collected for the years 2013 and 2014. Properly marked bamboo sticks were installed in each pond, and water levels were measured periodically and after each rainfall event. Water depth was also recorded by this method.

The amount of well/canal water added to the ponds could be estimated (Boyd 1982) using the following equation:

$W=(E+S+O+H)-(P+R)$

where $W$ water from well, $E$ evaporation, $S$ seepage, $O$ overflow, $H$ pond water depth, $P$ precipitation (rainfall), and $R$ run-off. Values for the above equation were in centimetres of water depth. In the present study, there was no overflow of water in any of the ponds. The pond dyke was well compacted and had grass cover. About $67 \%$ of rain falling on the dyke entered the ponds as run-off (Yoo and Boyd 1994). The equation for determining run-off for a pond was as follows:

$R=0.67(a / A) P$

where $a$ dyke area $\left(\mathrm{m}^{2}\right)$ and $A$ pond surface area $\left(\mathrm{m}^{2}\right)$.

Class A evaporation pan was used for the measurement of evaporation from the ponds in centimetres using the pan coefficient for evaporation as 0.81 (Boyd 1985). The seepage was estimated in centimetres as the difference in the decrease in water level and evaporation. Data on water gain and water loss and well/canal water additions calculated using the above equation were used to prepare water budgets for the fish culture of these ponds. The evaporation and seepage loss were measured daily, while the rainfall and run-off were recorded as and when they occurred.

\section{Results and discussion}

\section{Sources of water (water gain)}

The rainfall and run-off are the main water sources in these ponds which are presented in Figs. 1 and 2. The maximum rainfall of $88 \mathrm{~cm}$ occurred in the month of October in 2013, while the same was $77.7 \mathrm{~cm}$ in the month of July 2014 . There was no rainfall in January, March, November, and December months of 2013 and January, February, March, November, and December months of 2014. The total rainfall was $175 \pm 3.0 \mathrm{~cm}$ in 2013 and $202 \pm 5.0 \mathrm{~cm}$ in 2014 . The average rainfall was $0.48 \mathrm{~cm} / \mathrm{d}$ in 2013 and $0.55 \mathrm{~cm} / \mathrm{d}$ in 2014. Total run-off was $36 \pm 1.2 \mathrm{~cm}$ and $29 \pm 1.0 \mathrm{~cm}$ in 2013 and 2014, respectively.

The rainfall, run-off, and inflow of water from the canal/ well are considered as water gain in these ponds. The water added to these ponds to maintain the water level amounted to 32 and $37 \%$ of the overall water gain in the ponds in 2013 and 2014, respectively (Fig. 3). The rainfall was the most significant source of water accounting for 57 and $55 \%$ of the water gain in 2013 and 2014, respectively. The run-off in these ponds amounted to only 11 and $8 \%$ of the water gain, respectively, in both the years, and this may be due to small dyke area around the pond. Green and Boyd (1995) also reported $4.5 \%$ run-off as the water gain in their study at El Carao.

\section{Loss of water}

The water loss mainly occurs through evaporation and seepage. The maximum evaporation of $16.11 \mathrm{~cm}(0.52 \mathrm{~cm} / \mathrm{d})$ was in January 2013, while the same was $19.92 \mathrm{~cm}(0.64 \mathrm{~cm} / \mathrm{d})$ in October 2014 (Fig. 4). Total evaporation was $110 \pm 5 \mathrm{~cm}$ in 2013 and $138 \pm 7 \mathrm{~cm}$ in 2014 . The average evaporation
Fig. 1 Total rainfall and \% contribution to the pond water for each month of 2013 and 2014
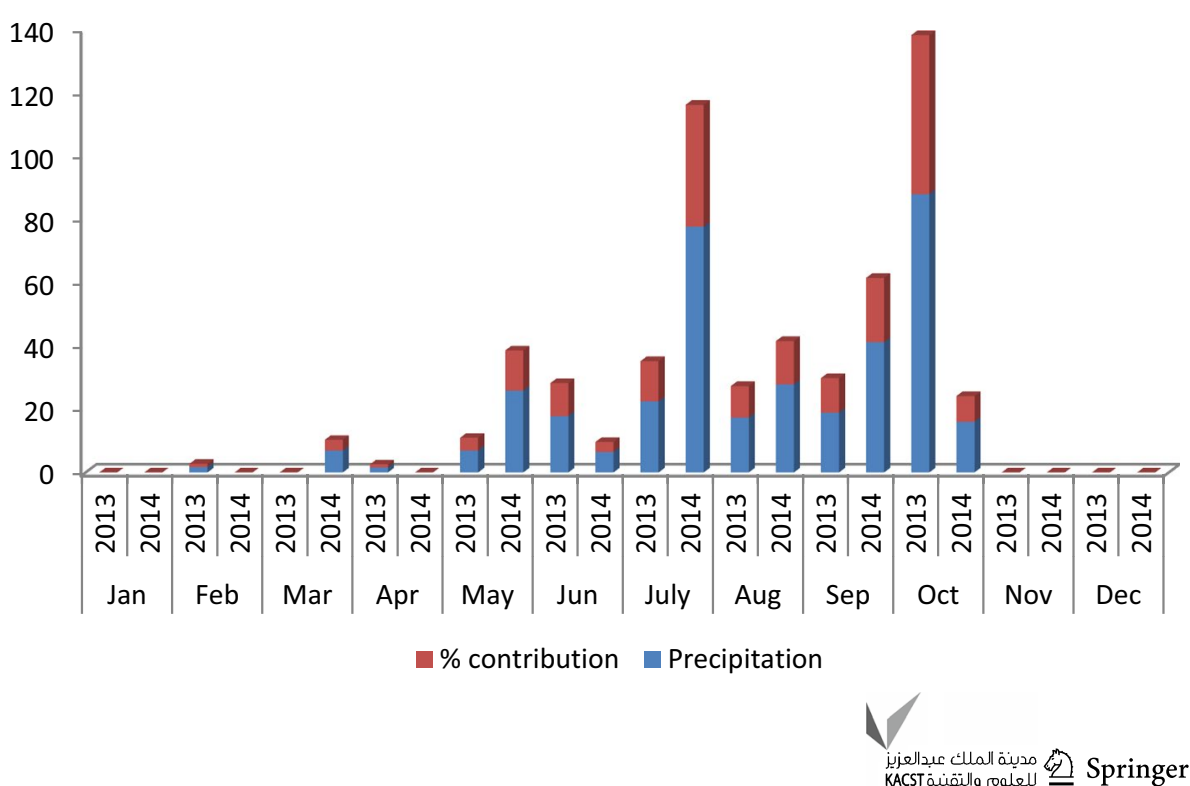
Fig. 2 Total run-off and \% contribution to the pond water for each month of 2013 and 2014

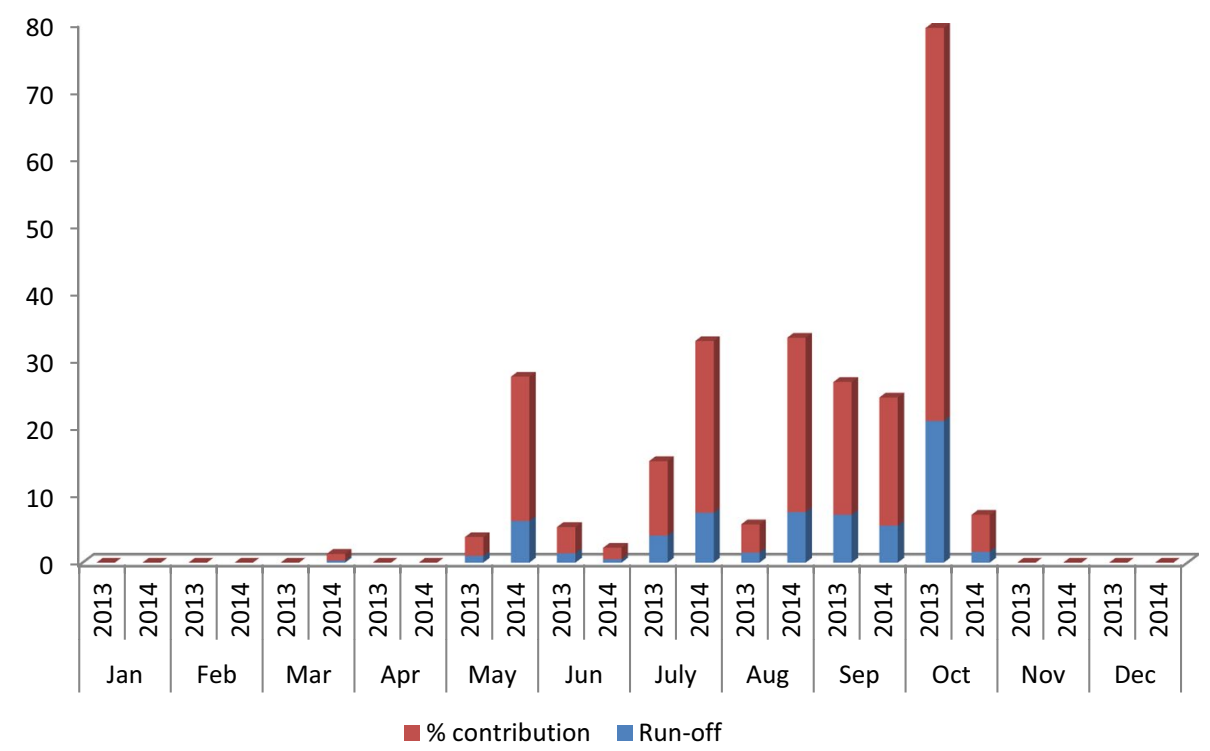

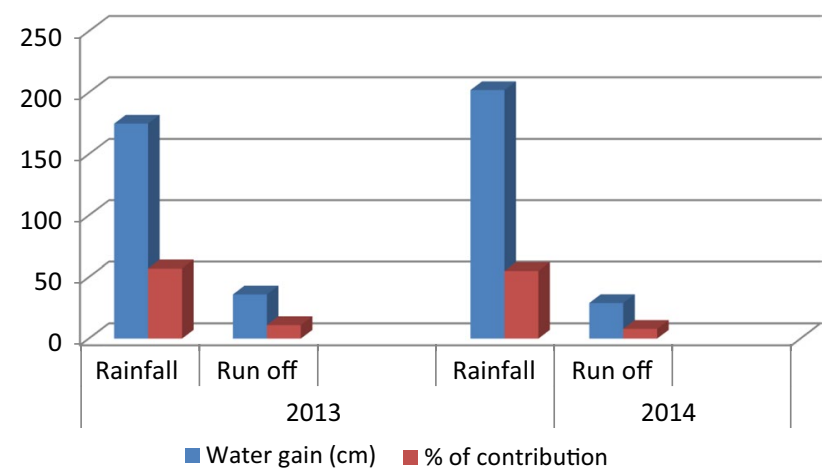

Fig. 3 Precipitation and run-off and their contribution in water gain percentage during 2013 and 2014

was $0.30 \mathrm{~cm} / \mathrm{d}$ in 2013 and $0.37 \mathrm{~cm}$ in 2014 . The maximum seepage loss was $17.8 \mathrm{~cm}(0.59 \mathrm{~cm} / \mathrm{d})$ in November 2013 and $14.2 \mathrm{~cm}(0.47 \mathrm{~cm} / \mathrm{d})$ in September 2014 (Fig. 5). The total seepage was around $80 \mathrm{~cm}$ in both the years. Thus, the average seepage loss was $0.22 \mathrm{~cm} / \mathrm{d}$ in both the years.

Evaporation and seepage contributed $58 \%$ and $42 \%$ of the water loss in these ponds, respectively, in 2013, while the same was $64 \%$ and $36 \%$ of the water loss in 2014 (Fig. 6). Evaporation and seepage loss vary from location to location. Evaporation contributed between 2.6 and $4.0 \mathrm{~mm} / \mathrm{d}$ in Nyangera and Kusa villages around Lake Victoria in Kenya (Kipkemboi et al. 2007). They also reported about the seepage loss of up to $7.6 \mathrm{~mm} / \mathrm{d}$ in Nyangera during the dry season of 2004. Nath and Bolte (1998) reported that evaporative loss was $0.45 \mathrm{~cm} / \mathrm{d}$ in Asian Institute of Technology (AIT) ponds. The overall evaporative loss in the present study was $0.33 \mathrm{~cm} / \mathrm{d}$. The evaporation loss from the ponds depends on the weather conditions, mainly humidity, dry weathers, size, and depth of the ponds. Boyd (1985) reported that seepage accounted for about $66 \%$ of the overall water loss for Auburn ponds, where seepage rates varied from 0.48 to $0.79 \mathrm{~cm} / \mathrm{d}$. Nath and Bolte (1998) reported that seepage rate varied from
Fig. 4 Total evaporation and \% contribution for water loss from the pond of each month of 2013 and 2014

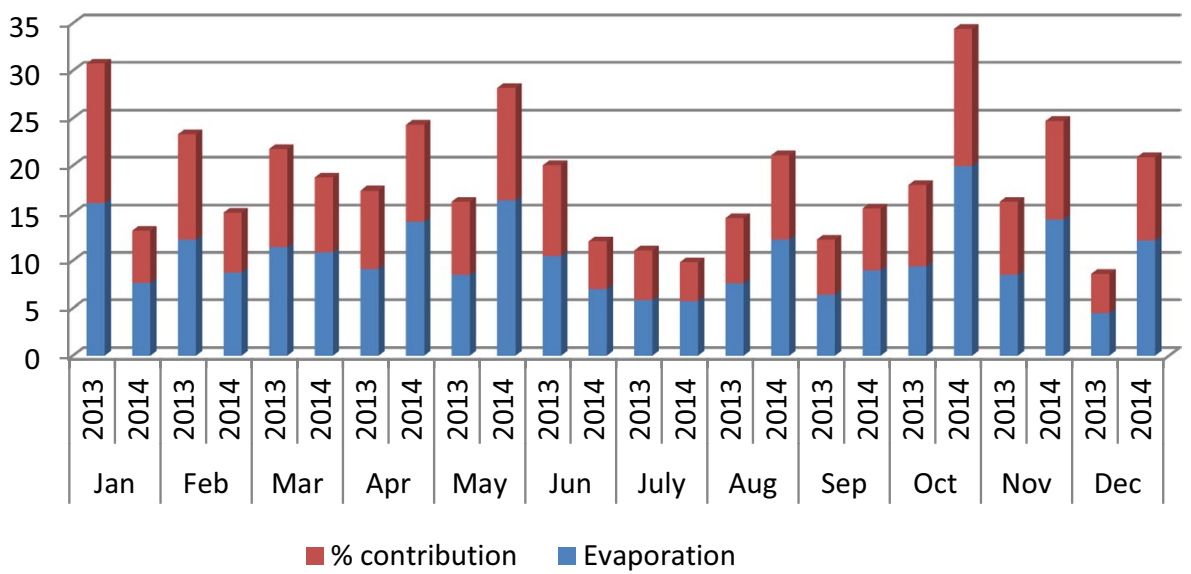


Fig. 5 Total seepage and \% contribution for water loss from the pond of each month of 2013 and 2014

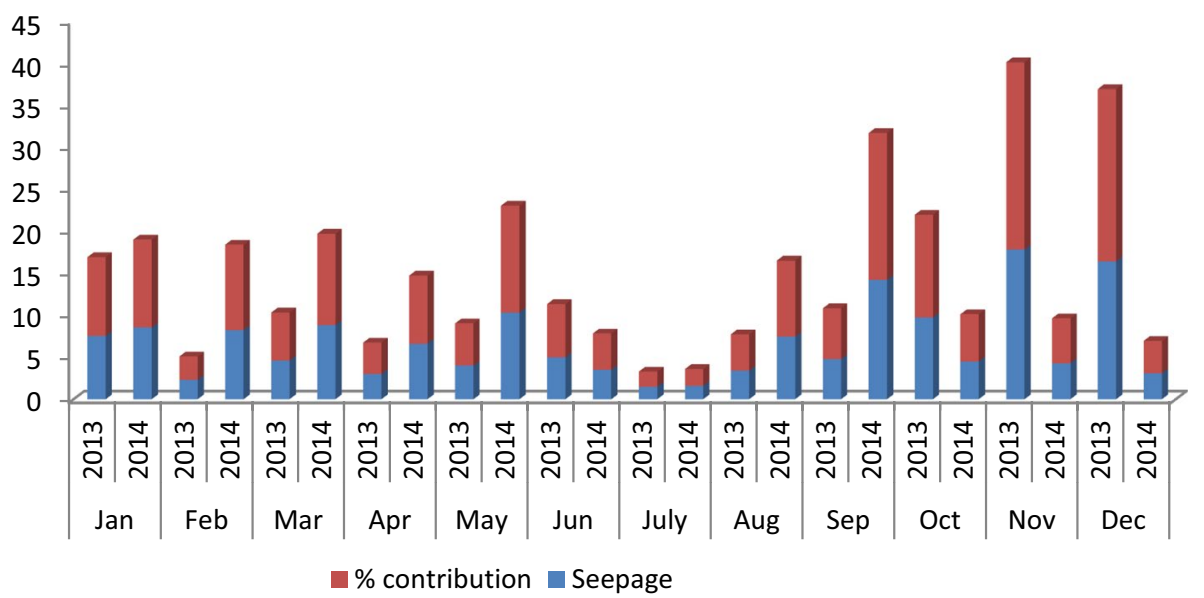

respectively. In both the years, the minimum depth of the water was observed in the month of May. The maximum water depth was in the month of September in both the years.

\section{Water budget}

The water gain and loss and the water budget are presented in Figs. 3 and 6. It is evident from the figure that the rainfall was the main source of water. The rainfall plus run-off was about $21 \mathrm{~cm}$ more than evaporation and seepage in 2013, while the same was $12 \mathrm{~cm}$ more than evaporation and seepage in 2014. Evaporation was the main loss of water followed by the harvested water. Though evaporation was a major loss of water, nutrients were not lost via this route (Boyd et al. 2007). Nutrients were mainly lost through the harvested water.

The total amount of well/canal water in an average year to compensate the water loss through evaporation and seepage was $98 \pm 2 \mathrm{~cm}$ and $137 \pm 3 \mathrm{~cm}$ of water in 2013 and 2014, respectively (Fig. 8). Accordingly, $9800 \pm 200 \mathrm{~m}^{3}$ of water in 2013 and $13,700 \pm 300 \mathrm{~m}^{3}$ of water in 2014 would be required as added water for the 1.0 ha pond.

The harvested water in 2013 and 2014 was $120 \pm 2$ and $150 \pm 3 \mathrm{~cm}$, respectively. Accordingly, the harvested water could be $12,000 \pm 200 \mathrm{~m}^{3}$ and $15,000 \pm 300 \mathrm{~m}^{3}$ in 2013 and 2014 , respectively, for the 1.0 ha pond. This water is drained out from the pond and utilized as irrigation water for some horticultural crops. Sometimes, this water is retained in the pond and allowed to mix with rain water and then used for the fish culture purposes. If required, this harvested water is treated with alum and lime for settling down the organic matter and plankton from the water and then used for culture purposes. Thus, the harvested water is not considered as water loss.

The total water use in aquaculture pond is the amount of precipitation, run-off, and other natural processes like seepage in and water applied through well or canal for the pond was $166+6 \mathrm{~cm}$ in 2013 and $197 \mathrm{~cm}$ in 2014 , 


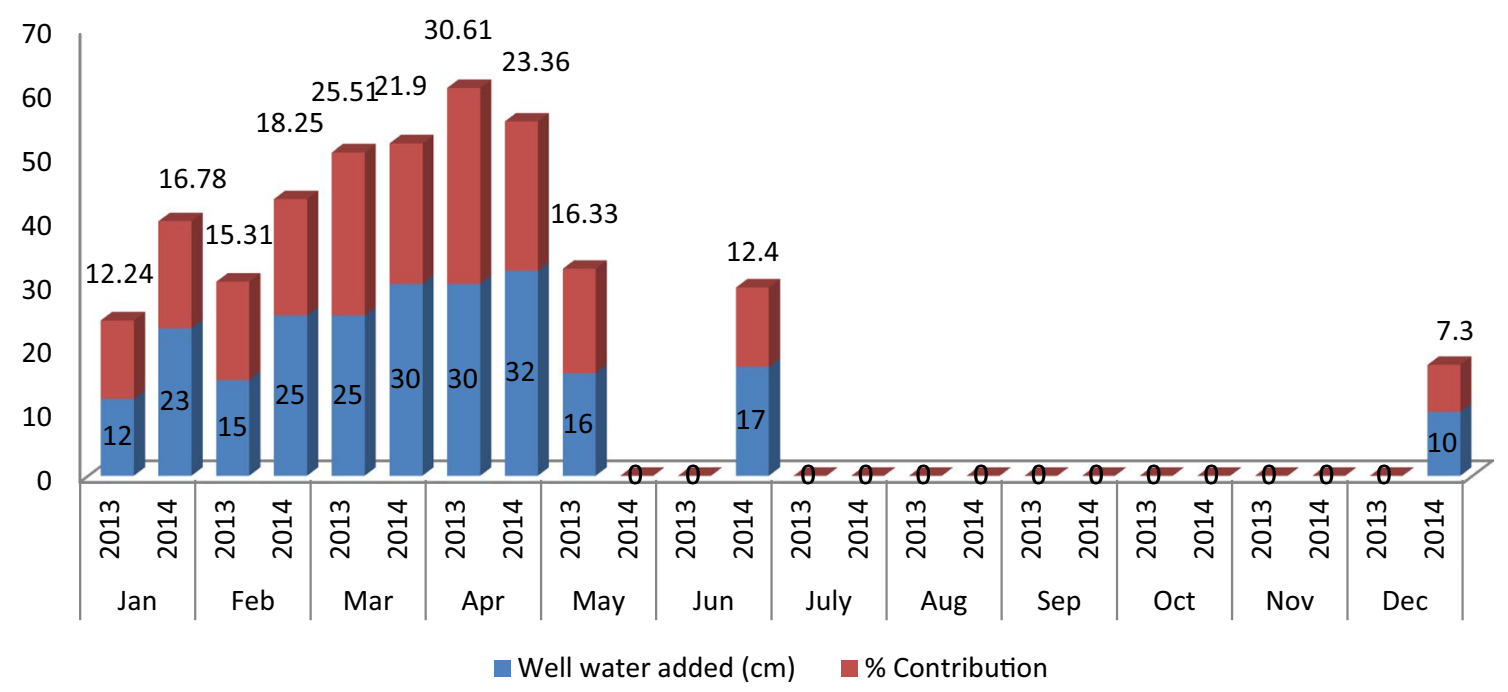

Fig. 8 Total water addition (inflow water) and \% contribution to the pond water for each month of 2013 and 2014

the management practices. Accordingly, total water use in the present study could be $309 \pm 11.0$ and $368 \pm 12.0 \mathrm{~cm}$ in a year which could be equivalent to $30,900 \pm 1100$ and $36,800 \pm 1200 \mathrm{~m}^{3}$ for a hectare of a pond in 2013 and 2014 , respectively.

The consumptive water use for an aquaculture pond consists of water losses due to evaporation and seepage. Accordingly, the consumptive water use could be $189 \pm 1.8$ and $218 \pm 2.0 \mathrm{~cm}$ in a year of culture period which could be equivalent to $18,900 \pm 180$ and $21,800 \pm 200 \mathrm{~m}^{3}$ for a hectare pond in 2013 and 2014, respectively. The consumptive water use was $0.51 \mathrm{~cm} / \mathrm{d}$ and $0.59 \mathrm{~cm} / \mathrm{d}$ in 2013 and 2014, respectively, in the present study.

Water use could also be computed in terms of production. Fish production was $6000 \pm 300$ and $6500 \pm 350 \mathrm{~kg} /$ ha in these ponds in 2013 and 2014, respectively, in the present study. Accordingly, consumptive water use was $3.15 \pm 0.3 \mathrm{~m}^{3} / \mathrm{kg}$ fish and $3.35 \pm 0.2 \mathrm{~m}^{3} / \mathrm{kg}$ fish in 2013 and 2014 , respectively. The total water use in these embankment ponds was $5.15 \pm 0.5 \mathrm{~m}^{3} / \mathrm{kg}$ fish and $5.66 \pm 0.6 \mathrm{~m}^{3} / \mathrm{kg}$ fish in 2013 and 2014, respectively. It is evident that both consumptive and total water use could decrease with an increase in fish production without any negative impact on the environment. The consumptive water use index for channel catfish in Alabama was $3.306 \mathrm{~m}^{3} / \mathrm{kg}$ fish in 1997 (Boyd 2005).

\section{Conclusion}

From the above discussion, it is evident that evaporation and seepage play a vital role so far as water loss is concerned. The rainfall and run-off are slightly higher than the evaporation and seepage in both the years. Thus, the addition of water from the well/canal is very vital to maintain the storage change in the pond. This study also demonstrated that on an average, an amount of $100 \mathrm{~cm}$ or $100,00 \mathrm{~m}^{3}$ of water in a year could be required for the 1.0 ha pond for successful fish culture in the region. The consumptive water use was $3.15 \pm 0.3 \mathrm{~m}^{3} / \mathrm{kg}$ fish and $3.35 \pm 0.2 \mathrm{~m}^{3} / \mathrm{kg}$ fish in 2013 and 2014 , respectively, while the total water use in the embankment ponds was $5.15 \pm 0.5 \mathrm{~m}^{3} / \mathrm{kg}$ fish and $5.66 \pm 0.6 \mathrm{~m}^{3} / \mathrm{kg}$ fish in 2013 and 2014, respectively.

Acknowledgements The authors are grateful to the Director of ICARCentral Institute of Freshwater Aquaculture for providing necessary facilities to carry out the present work. The authors are also grateful to Mr. Dilip Badajena for his generous help for carrying out the present study in these ponds.

Open Access This article is distributed under the terms of the Creative Commons Attribution 4.0 International License (http://creativeco mmons.org/licenses/by/4.0/), which permits unrestricted use, distribution, and reproduction in any medium, provided you give appropriate credit to the original author(s) and the source, provide a link to the Creative Commons license, and indicate if changes were made.

\section{References}

Boyd CE (1982) Hydrology of small experimental fish ponds at Auburn, Alabama. Trans Am Fish Soc 111:638-644

Boyd CE (1985) Chemical budgets for channel catfish ponds. Trans Am Fish Soc 114:291-298

Boyd CE (2005) Water use in aquaculture. World Aquac 36(3):12-15 Boyd CA, Boyd CE, Rouse DB (2007) Potassium budget for inland, saline water shrimp ponds in Alabama. Aquac Eng 36:45-50

Braaten RO, Flaherty M (2000) Hydrology of inland brackishwater shrimp ponds in Chachoengsao, Thailand. Aquac Eng 23:295-313 
Briggs MRP, Funge-Smith SJ (1994) A nutrient budget of some intensive marine shrimp ponds in Thailand. Aquac Fish Manag 25:789-811

Green BW, Boyd CE (1995) Water budgets for fish ponds in the dry tropics. Aquac Eng 14:347-356

Kipkemboi J, Van Dam AA, Mathooko JM, Denny P (2007) Hydrology and the functioning of seasonal wetland aquaculture-agriculture systems (Fingerponds) at the shores of Lake Victoria, Kenya. Aquac Eng 37:202-214

Mohapatra BC, Mahanta SK, Sahu H, Majhi D (2016) Water budgeting of portable FRP carp hatchery for Rohu, Labeo rohita Spawn Production. Curr World Environ 11(2):610-618

Nath SS, Bolte JP (1998) A water budget model for pond aquaculture. Aquac Eng 18:175-188
Sharma KK, Mohapatra BC, Das PC, Sarkar B, Chand S (2013) Water budgets for freshwater aquaculture ponds with reference to effluent volume. Agric Sci 4(8):353-359

Shelton J, Boyd CE (1993) Water budgets for aquaculture ponds supplied by runoff, with reference to effluent volume. J Appl Aquac 2(1):1-27

Verma AK, Cherian J, Chandra P (2010) Water budgeting studies on the hatchery and nursery rearing practices for the common carp, Cyprinus carpio (Linnaeus, 1758). J Indian Fish Assoc 37:7-17

Yoo KH, Boyd CE (1994) Hydrology and water supply for aquaculture. Chapman and Hall, New York

Publisher's Note Springer Nature remains neutral with regard to jurisdictional claims in published maps and institutional affiliations. 